\title{
SCIENTIFIC CONCEPT ACCORDING TO ISLAMIC PERSPECTIVE
}

\author{
Salamiyah
}

Chemistry Education Study Program, UIN Antasari Banjarmasin, Indonesia

Email: salamiahgrogot11@gmail.com

\author{
Website: http://jurnal.uin-antasari.ac.id/index.php/itijk \\ Received: 9 March 2020; Accepted: 16 September 2020; Published: 17 December 2020
}

\begin{abstract}
The scientific approach is the learning process with the activities of observing, asking, processing, presenting, concluding and creating. In Islamic there has been explained an explanation of the process of learning. Regarding this includes the process of working memory, mastery of knowledge and skills. This research uses the literature method and the data are analyzed descriptively. The scientific concept in Islamic has been carried out by prophets and apostles and has been developing until now. We can take a scientific approach from the story of Adam about knowing the names (Asma) and Abraham in seeking God. In both stories there is a scientific concept process that is (1) observing, (2) asking, (3) gathering information, (5) associating, and (6) communicating.
\end{abstract}

Keywords: learning process; scientific concepts; islamic perspective

\section{INTRODUCTION}

Implementation Curriculum 2013 very affect the activity or studying processes that into active learning. This studying process must lead to all students potentially have. National education purposes is to have competence. In order to advance Indonesia education, young generation must creative, innovative, effective and productive. In that case it is necessary to have stronger knowledge, skills, and integration so that can answer all kinds of educational problem in Indonesia. To achieve educational quality, required all kinds of new creativity to get effective and have certain qualities in education. Learning in ethics, value, aesthetic, kinesthetic, and logical required to have fun and challenging condition. Through the application of various strategies and fun learning methods can form a diverse learning experience. This Curriculum 2013 in Indonesia with scientific approach to improve curriculum for better learning experience in educations world (Nurlatifah, 2019).

In the learning process with the scientific approach used, it can lead students to acquire new knowledge by actively finding information, uncovering problems that combine knowledge (Dewi S., 2019). The stages in the learning process in a scientific approach are (1) observing, (2) asking, (3) processing, (4) presenting, (5) concluding, (6) creating.

The scientific approach in Islam has been carried out by several prophets and apostles as well as Islamic figures. Islam has also explained the learning process including working memory, mastery of knowledge and skills. The Qur'an has given signs regarding the explanation of the learning process. The existing learning methods in Islam include (1) imitation, indirectly humans always experience it. (2) experience, and (3) practical. Humans actually learn from childhood by imitating like talking, walking, as well as other habits. The discussion that will be reviewed next is about scientific concept according to perspective Islam

\section{RESEARCH METHOD}

This article used qualitative design for examine scientific concept according to Islamic perspective. The method used in this journal is literature, as for some article 
reference (1) Nurlatifah, 2019, (2) Fasih, 2016, (3) Habibillah, 2018, (4) Hidayah, 2014, (5) Khatimah, 2015, (6) Ritonga, 2017, (7) Sakilah, 2013, (8) Dewi, 2019, dan (9) Sumanto, 2018. After gathering data related to scientific approach then reviewed for knowing Islamic perspective about scientific approaches. Then the data were analyzed by descriptive approach. The main source used for research refers to article by Khatimah, 2015.

\section{RESULT AND DISCUSSION}

\section{Learning with Scientific Approach}

The Scientific approach exists because the Regulation of Minister of Education and Culture of the Republic of Indonesia number 65 of 2013 affirms that in education for curriculum 2013 implemented with scientific approach. Scientific approaches expected to develop attitude, knowledge and student's skill. The learning processes previously focused on the teacher, with a scientific approach it is hoped that will change learning process to focus on students. This approaching method gave learning experience, there are (1) observe, (2) asking, (3) gathering information, (4) processing information, and (5) discussion. Those activities leaning on observe activity, logical thinking, finding, and explanation about truth. Therefore, studying process must be implemented by scientific principle. (Ritonga, 2017).

\section{Scientific approach stages}

Scientific approach stages in learning process as follows : (Khatimah, 2015).

\section{a. Observe}

The activity of observing students observe using one or more of the five senses such as sight, listen, smell, taste, and touch. In this case like saw a pencil, hearing a bird sound, taste an apple, and touch a wooden. The purpose of observation activity is to gather information from existing data.

\section{b. Ask}

The next activity teacher gave opportunity to students for asking about anything they had observed. Teacher directed to ask questions about the results of observation made.

\section{c. Gathering Information}

This activity is after asking stage. Purposes for this activity is to gathering information from various sources through many ways so information will be gather. This activity can be carried out by students with various activities such as reading books, observing an object, interviews or experiments.

\section{d. Associate}

After getting data from previous activities. The next activity is associating (processing information) from the results of observing to gathering information. In these activities can add depth and understanding of information. In this case, the search for a solution can be done with various sources who have different opinions.

\section{e. Communicate}

The next activity is communicate. Communicating can be done either by writing or telling about what is being sought that is obtained from previous activities. This activity is to presenting results to conclusion either orally, writing, or with other media.

\section{Learning Process in Islamic Perspective}

The learning process in Islam provides physical and spiritual needs in a balanced manner. Because from that it will give birth to one-way thought and dhikr to make humans according to dignity, either individually, socially or spiritually. The verses regarding to basic education in Islam are found in Surah al-Alaq: 1-5

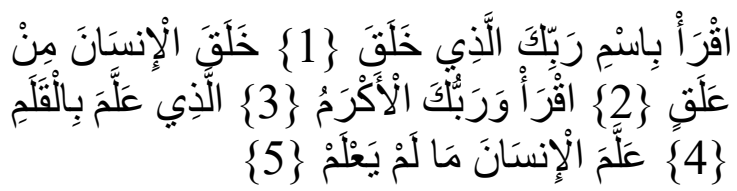


Meaning:

(1) Read with (mention) the name of your Lord who created. (2) He created man from a clot of blood. (3) Read, and it is your Lord who is gracious. (4) The one who teaches (humans) through qalam. (5) He teaches people what he does not know. (Surah AlAlaq: 1-5).

The verses above explain that one of the goals of the Qur'an is to educate humans with tadabbur and with logic method in the form of reading, researching education, and observation. Therefore, in Islam education prioritizes understanding the concept. (Fasih, 2016).

The attainment of humans in the most noble positions is the goal of deep learning Islam. Islam has explained about the learning process which includes work process memory, mastery of knowledge and skills. The concept of cognitive and sensory (five senses) as an important tool in the learning process. Both of these also affect the success and failure of acquiring knowledge both in the long and short term. Every human being is born without knowledge (an empty state), then provision of physical potential that is given by Allah SWT to learn by developing science and technology for the benefit of all. The potential given by Allah is very helpful in learning activities, namely (1) the sense of sight which functions to receive information or data visually, (2) the sense of hearing which functions to receive information or data verbally and (3) the sense which functions to capture, analyze , store, and recreate from information or knowledge. These three things play an active role in learning activities that are interconnected and functionally supportive. Allah says in surah an-Nahl verse 78 which reads:

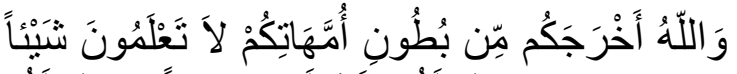

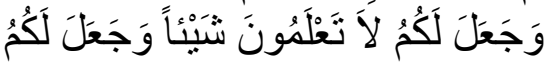

Meaning:

"And Allah brought you out of your mother's stomach in a state of not knowing anything, and He gave you hearing, sight and heart, so that you may be grateful" (Surah AN-Nahl: 78).

In the above verse the most important thing is reasoning or good reasoning power will be able to manage all the potential that is in him. In learning which is also a process of increasing the ability and functioning of the three things that have been mentioned above as has existed since the creation of the first human on earth, namely Prophet Adam.

The environment is one source of knowledge that can be learned, as a hadith narrated by Bukhari:

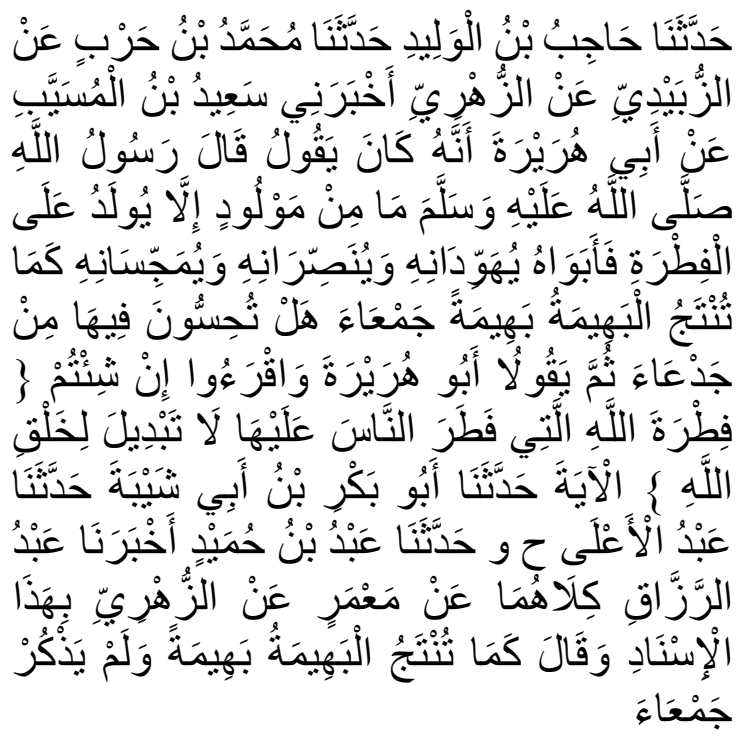

Meaning:

"Having told us Hajib bin Al Walid told us Muhammad bin Harb from Az Zubaidi from Az Zuhri had reported to me Sa'id bin Al Musayyab from Abu Hurairah, he said; "The Messenger of Allah -peace and prayer of Allah be upon him- said: 'A baby is not born (into this world) but he is in purity (fitrah). Then both his parents will make him a Jew, Christian, or Magi like an animal that is born safe without So, do you feel a defect? "Then Abu Hurairah said;" If you want, then read the word of Allah which reads: "... keep on the nature of Allah who created man according to his nature. There is no change in the fitrah of Allah." (Surah Ar Ruum (30): 30). Has 
told us Abu Bakr bin Abu Syaibah; has told us' Abdul 'Alaa Likewise narrated from another route, and has told us' Abd bin Humaid; has reported to us' Abdurrazzaq both from Ma'mar from Az Zuhri with this sanad and he said; 'As livestock give birth to their young without mentioning flaws. "(Narrated by Bukhari).

The hadith above is incarnate grasp how every human being is born has the potential both good and evil potential. This potential is formed according to the existing environment, especially parents because they are the ones who play a big role in making this potential (Hidayah, 2014).

The most important process of learning is perfecting human understanding. The language skills that exist in humans are very important to help accelerate the formation of various conceptions in the process of thinking, studying, and analyzing various new information. Another ability, namely thinking that exists in humans, can assist in analyzing, composing, differentiating, discovering, and formulating (Sakilah, 2013).

\section{Scientific Approach in Islam}

The scientific concept has long been carried out by the prophets or messengers in events they experienced with the permission of Allah. The following is a positive approach taken by the prophets and apostles:

\section{a. The Story of the Prophet Adam to Know the Names}

The story of the teachings of the Prophet Adam as. Regarding the names of objects that are visible to the eye and proof of the fallacy of angels' views, it is found in surah Al-Baqarah verses 31-33 which reads:

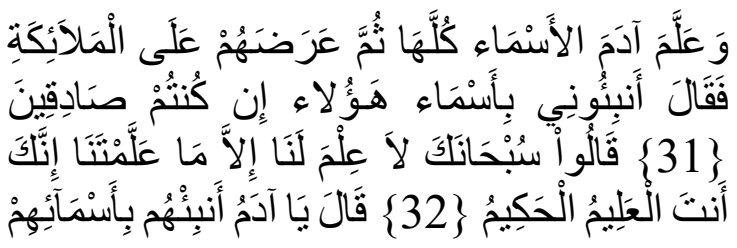

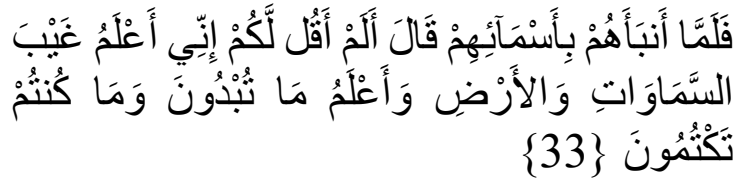

Meaning:

"(31) And He taught Adam the names (of things) all of them, then presented them to the angels, then said," State the names of those things if you are true people! " (32) They replied: "Glory to you, we do not know anything other than what You have taught us, verily you are the one who knows, the most wise." (33) Allah said: "O Adam, tell them the names of these objects. Allah said, "Didn't I tell you that I know the secrets of heaven and earth and know what you gave birth to and what you hid?" (Surah Al-Baqarah: 31-33).

The verse above describes the teaching to Prophet Adam who was the source of knowledge information to take advantage. The system of teaching the Prophet Adam uses a language that teaches the names first, not the verbs (Habibillah, 2018).

Allah introduced names (Asma ') with language and enabled Prophet Adam to express concepts and understandings. Prophet Adam learned from what was around him. In addition, he is able to master symbols that enable him to think and communicate in order to receive knowledge and gain value through scientific analysis. Prophet Adam's learning process started from the exploration of natural phenomena as natural knowledge, recognizing the nature and characteristics. In the end, he was able to explain, mention, and formulate words regarding the conception or meaning of names through the angels commanded by Allah. The results of the Prophet Adam's lessons actually occurred and were continued in the generations of humans after that (Sakilah, 2013). Based on the story of the introduction of names to the prophet Adam, there is a process of (1) observing these names, (2) collecting data that occurs in natural phenomena, (3) 
associating with knowledge of the nature, characteristics and knowledge of nature, and (4) communicate by explaining, mentioning, and formulating words regarding the conceptions or meanings of the names that He taught.

\section{b. The story of the Prophet Abraham in Seeking God}

The Qur'an has told how Prophet Abraham sought the truth about God which is found in surah Al-An'aam verses 74-79 which reads:

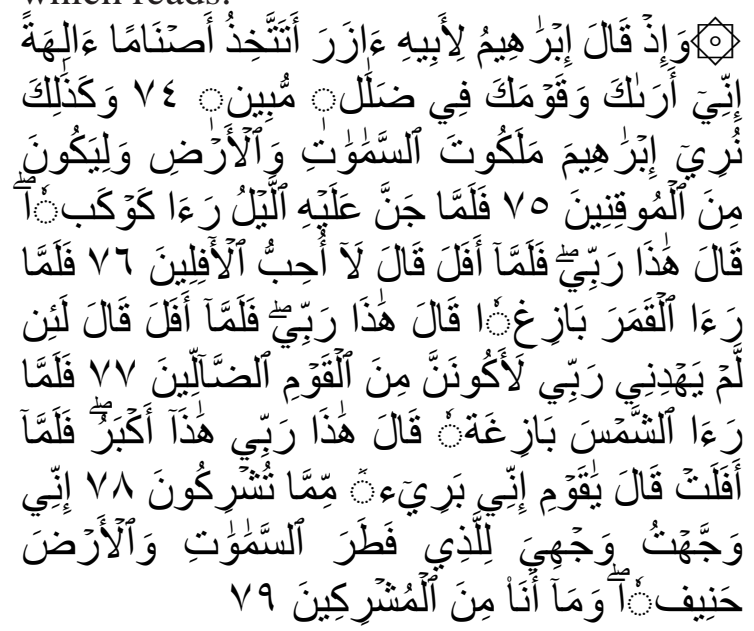

Meaning:

"(74) And (remember) when Abraham said to his father," Is it fitting that you make idols as God? ", Verily I saw you and your people in apparent error. (75) And thus We showed Abraham the power (We who were) in the heavens and the earth, and that he was among those who believed. (76) When the night had become dark, he (Ibrahim) saw a star (then) he said, "Is this my Lord?", Mka when the star set he said, "I do not like what is setting". (77) Then when he saw the rising moon he said, "Is this my Lord?", But when the moon set he said, "Indeed, if my Lord had not instructed me I would have been among those who were perverted. (78) Then when he saw the sun rise he said, "This is my Lord? this is bigger. But when the sun went down, he said, "O my people! Really, I break away from what you associate. (79) I turned my face to Allah who created the heavens and the earth with full submission (following) the great religions, and I am not among the polytheists "(Surah Al-An'aam: 74-49).

One day Abraham saw his people worshiping a statue, that's when his mind didn't accept it. After that he contemplated on the cave wall by looking up at the night sky. Looking up he saw the many stars twinkling beautifully. Finally he thought that the stars were God and believed that the same as those who worship the stars.

Shortly after that Prophet Ibrahim saw the moon which was much bigger than the star. He told his people that the moon was their Lord because its light was brighter than the stars. The following night, Ibrahim did not see the moon in the sky. Then he thought the moon and stars could disappear. The next day, he thought that the moon and stars were not God because they could disappear. Then he looked again at the sky and there was a light greater than the moon, the sun. He also believed that it was his God, because the sun had the brightest light which indicated that God was the most manly. When night fell, the sun also set Abraham thought again that God could not possibly sink. After

Prophet Abraham observed everything in the sky, he was silent while contemplating about something that is the brightest, strongest, and will never sink. Based on what Abraham had experienced, he understood that what he admired such as stars, moon and sun could appear and then depart. Prophet Abraham then thought that God could not be like that who appeared and then left. In the end Prophet Ibrahim came to the conclusion that God created the stars, the moon, and the sun and make them appear and disappear. Ibrahim told his people that the universe including life for humans, God created it (Sumanto, 2018).

The process that Prophet Abraham went through in seeking and finding the truth about God. Here he goes through the process of making use of the development of the potential of the body (physical), the potential of the mind (reason, ratio) and the potential of the heart (heart). (Suyanta, 
2007). Based on the story of Prophet Abraham looking for God, there is a scientific process including (1) observing, he saw a statue that was worshiped by his people, (2) asking him, Ibrahim did not accept what he saw then a question arose about his right to be worshiped, (3) gathering information, make observations and seek about God who is entitled to worship through the moon, stars, and sun that appear in the sky, and (4) associating, Abraham pondered with what he passed and everything that could arise and fall. Then he thought that there couldn't be God like that. And (5) communicating, Abraham concluded that God created the stars, moon and sun and made them appear and disappear.

Based on the two stories above, regarding the scientific approach in Islam can be seen in table 1 below:

Table 1. Scientific Approach in Islam

\begin{tabular}{|l|l|l|}
\hline No. & \multicolumn{2}{|c|}{ Islamic perspective } \\
\hline 1. & $\begin{array}{l}\text { The introduction of the } \\
\text { names to the prophet Adam }\end{array}$ & $\begin{array}{l}\text { Observe against the names. } \\
\text { Gather data through phenomena that occur. } \\
\text { Associate knowledge about the nature, characteristics, and natural knowledge } \\
\text { Communicating } \\
\text { by explaining, mentioning, and formulating words regarding the conceptions } \\
\text { or meanings of the names he taught. }\end{array}$ \\
\hline 2. & Ibrahim sought God & $\begin{array}{l}\text { Observe the statue worshiped by the people. } \\
\text { Ask the question of who has the right to be worshiped by him. Gathering } \\
\text { information seeking about a God who is entitled to worship through the moon, } \\
\text { stars, and sun that arises in the sky, Associates Abraham contemplating with } \\
\text { what he has passed and everything that can arise and sink. Then he thought that } \\
\text { there couldn't be God like that. drowned, this meant God couldn't be like that. } \\
\text { Communicating } \\
\text { Abraham told his people that God created the universe and gave life }\end{array}$ \\
\hline
\end{tabular}

\section{CONCLUSION}

The scientific approach that is in the 2013 curriculum which in the learning process is centered on students. The scientific approach includes activities observe, ask questions, gather information, associate and communicate. The learning process in Islam involves the five senses, both sight, hearing, smell, touch, or taste. Besides that, it also takes advantage of the potential that is owned since birth. The scientific concept has long existed and was used by prophets and messengers and other Islamic figures. We can take a scientific approach in Islam from the story of Prophet Adam about knowing the names (Asma ') and Prophet Abraham in seeking God. Both stories contain $5 \mathrm{M}$ activities (observing, asking, collecting, informing, associating, and communicating) which are the basic concepts of the scientific approach.
Because they are full of education, other stories need the attention of researchers. It is a scientific truth and research that is relative in nature, so it is recommended to research and examine more intensively. It is just that through the study of scientific concepts according to an Islamic perspective this can be used as interpretive enrichment material for later researchers.

\section{REFERENCES}

Fasih, A. R. (2016). Dasar-dasar Pendidikan Islam dalam Tinjauan AlQur'an dan Al-Hadist. Jurnal Studi Pendidikan Vol.XIV, No. 1 , 78-87.

Habibillah. (2018). Nilai-nilai Pendidikan yang Terkandung dalam Kisah Adam (Kajian Tafsir Al-Qur'an Surah AlBaqarah 2;30-39. UIN Syarif Hidayatullah: Fakultas Ilmu Tarbiyah dan Keguruan . 
Hidayah, A. S. (2014). Hadis-hadis tentang Peserta Didik. Nadwa: Jurnal Pendidikan Islam, Vol.8, No. 1, 1-16. Khatimah, N. (2015). Pendekatan Saintifik Dalam Implemantasi Kurikulum 2013 yang Berbasis Pendidikan Karakter. Humanis , VII (2), 157-164. Nurlatifah, d. (2019). Pengaruh Penerapan Pendekatan Saintifik Berbasis Eksperimen Terhadap Kemampuan Berpikir Kritis. Jurnal Pendidikan Fisika, Vol. 7, No. 2 , 184-188.

Pendekatan Saintifik Pembelajaran Pendidikan Agama Pada Sekolah Dasar Islam Terpada. (2017). Asnil Aidah Ritonga , 78-97.

Ritonga, A. A. (2017). Pendekatan Saintifik Pembelajaran Pendidikan Agama Pada Sekolah Dasar Islam Terpadu. Miqot, XII (10), 78-97.

Sakilah. (2013). Belajardalam Perspektif Islam. Menara , XII (2), 156-164.

Sumanto, E. (2018). Filosofi Nabi Ibrahim Mencari Tuhan Melalui Bulan, Bintang dan Matahari. Nuasa, XI (2), 125-132.

Suyanta, S. (2007). Kisah Ibrahim Mencari Tuhan dan Nilai-nilai Pendidikan. Islam Futura, Vol. 6, No. 2 , 100-118. 